\title{
Stem cells and bronchial stump healing
}

\author{
David Gomez-de-Antonio, MD, $\mathrm{PhD},{ }^{\mathrm{a}}$ Mercedes Zurita, $\mathrm{MD}, \mathrm{PhD},{ }^{\mathrm{b}}$ Martin Santos, $\mathrm{MD}, \mathrm{PhD},{ }^{\mathrm{c}}$ \\ Isabel Salas, $\mathrm{MD},{ }^{\mathrm{d}}$ Jesús Vaquero, $\mathrm{MD}, \mathrm{PhD},{ }^{\mathrm{b}, \mathrm{c}}$ and Andres Varela, $\mathrm{MD}, \mathrm{PhD}^{\mathrm{a}}$
}

Objective: Bronchial stump dehiscence is still the most feared complication for the thoracic surgeon, with mortality rates ranging from $25 \%$ to $75 \%$. This study reports the histologic effect of adult stem cells in the healing process of the bronchial stump after lung resection.

\begin{abstract}
Methods: A left pneumonectomy was performed in 36 Wistar rats. Half of them received previously labeled bone marrow-derived stem cells applied to the bronchial stump. In each group, 7 rats were sacrificed on day 7 and 11 rats were sacrificed on day 21. Macroscopic variables and histopathologic features were analyzed.
\end{abstract}

Results: On days 7 and 21, there were fewer adhesions in the stem cell group ( $P=.042$ and .031 , respectively). Bronchial stump restitutio ad integrum on day 21 was found predominantly in rats from the stem cell group $(P=.012)$. At that time, the same group showed significantly less inflammation in every layer of the stump $(P<.050)$.

Conclusions: Bone marrow-derived stem cells administered topically on a bronchial stump are able to migrate, reach the bronchial wall, and participate in the healing process. This induces fewer adhesions, less inflammatory response, and better regeneration of the tissue. (J Thorac Cardiovasc Surg 2010;140:1397-401)

In recent years, countless studies dealing with the definition and isolation of stem cells in various embryonic and adult tissues have been performed. By definition, a stem cell is an undifferentiated cell with asymmetric division capacity that has the ability to give rise to another identical cell and a precursor of a progeny committed to a more specialized function, different from that of the tissue of origin. ${ }^{1}$ Embryonic stem cells are isolated from the embryo in the morula phase or from the inner mass of the blastocyst, and they can give rise to any cell line. ${ }^{2}$ Our study focuses on adult stem cells derived from bone marrow stromal cells (BMSCs). These are cells obtained from adult tissues or the fetus before birth. Adult stem cells have been isolated from the bone marrow, fat, intestine, skin, and liver, and several studies have shown their ability to give rise to more specialized cell lines (ie, bowel, liver, pancreatic cells, skin, muscle, bone, cartilage, and nervous system) when the proper stimulus and environmental conditions occur. ${ }^{3,4}$ Both in vivo and ex vivo, there is evidence to support the role of these cells in cicatrization and wound healing, although the pathways to achieve this are still unknown. ${ }^{5}$

Bronchial dehiscence still remains one of the most feared complications for a thoracic surgeon, with an incidence

\footnotetext{
From the Thoracic Surgery Department, ${ }^{\text {a }}$ Neuroscience Laboratory, ${ }^{\mathrm{b}}$ Surgical Research Department, ${ }^{\mathrm{c}}$ and Pathology Department, ${ }^{\mathrm{d}}$ Thoracic Surgery, Hospital Universitario Puerta de Hierro, Majadahonda, Madrid, Spain. Disclosures: None.

Received for publication Jan 11, 2010; revisions received Feb 23, 2010; accepted for publication March 12, 2010; available ahead of print April 19, 2010.

Address for reprints: David Gomez-de-Antonio, MD, PhD, c/Lino 11-3F, 28020,

Madrid, Spain (E-mail: dgavm@yahoo.es).

$0022-5223 / \$ 36.00$

Copyright (C) 2010 by The American Association for Thoracic Surgery

doi:10.1016/j.jtcvs.2010.03.009
}

ranging from $0.4 \%$ and $4 \%$ in the largest series and representing high rates of morbidity and mortality. ${ }^{6-8}$ Many factors have been associated with its occurrence (right pneumonectomy, chronic obstructive pulmonary disease, radiation, and chronic and debilitating diseases). ${ }^{6,7,9}$ Extensive experimental and clinical work has been done to develop a method for perfect closure of the bronchial stump while preventing dehiscence (mechanical devices vs manual suture, absorbable vs nonabsorbable material, running vs interrupted suture), but none of these methods have been shown to be superior to the others so far.

The current accepted practice among the community of thoracic surgeons is to reinforce bronchial sutures with vascularized tissue (ie, chest wall muscles, parietal pleura, azygous vein, pericardial fat pad, omentum) in sutures at risk, for example, after or before radiotherapy and bronchoplastic procedures, or after a pneumonectomy. ${ }^{7}$

We postulate that BMSCs may play a role in improving bronchial stump healing, thus preventing the occurrence of bronchial stump dehiscence. Our study describes the influence of BMSCs in bronchial stump healing after a pneumonectomy.

\section{MATERIALS AND METHODS \\ Isolation and Characterization of Bone Marrow Stromal Cells}

BMSCs were obtained from the large bones of 10 donor adult Wistar rats (weighing 250 to $300 \mathrm{~g}$ ) and expanded in vitro for 4 weeks. Bone marrow was mechanically dissociated to obtain a homogeneous cell suspension that was passed through $70-\mu \mathrm{m}$ nylon mesh. For purification, this sample was seeded on a Ficoll-Hypaque gradient (Beckman Coulter Inc, Fullerton Calif; density 1.077). The obtained cells were washed in $\mathrm{Ca}^{2+}$ and $\mathrm{Mg}^{2+}$ free Hanks' balanced salt solution and placed in a $75-\mathrm{cm}^{2}$ flask for tissue culture with $12 \mathrm{~mL}$ alpha-minimum essential medium containing $20 \%$ fetal bovine 


\section{Abbreviations and Acronyms \\ $\mathrm{BMSC}=$ bone marrow stromal cell \\ $\mathrm{BrdU}=5$-bromo-2'-deoxyuridine \\ GFP $=$ green fluorescent protein \\ PBS $=$ phosphate-buffered saline}

serum, $2 \mathrm{mmol} / \mathrm{L}$ l-glutamine, $100 \mathrm{U} / \mathrm{mL}$ penicillin, $100 \mu \mathrm{g} / \mathrm{mL}$ streptomycin, and $25 \mathrm{ng} / \mathrm{mL}$ amphotericin B. These cells were incubated at $37^{\circ} \mathrm{C}$ in $5 \% \mathrm{CO}_{2}$ for 3 days. At this time, nonadherent cells were removed by replacing the medium. The culture medium was replaced 3 times per week. After the primary cultures reached confluence, they were rinsed 3 times with phosphate-buffered saline (PBS) and dissociated with $0.25 \%$ trypsin and $1 \mathrm{mmol} / \mathrm{L}$ EDTA for 5 minutes at $37^{\circ} \mathrm{C}$ and subcultured at a density of $8 \times 10^{3}$ cells $/ \mathrm{cm}^{2}$. BMSCs were identified by their mesenchymal morphology and by cell surface expression of CD73, CD105, SH4, and vimentin, being negative for $\mathrm{CD} 34, \mathrm{CD} 45, \mathrm{CD} 3, \mathrm{CD} 14, \mathrm{CD} 19, \mathrm{CD} 38$, glycophorin A, and HLA II. ${ }^{10}$

\section{Labeling}

BMSCs were doubly labeled before transplantation. They were transfected with a retrovirus (pRV-IRES CopGFP2i) expressing green fluorescent protein (GFP) supplied by Genetrix S.L. (Madrid, Spain). They were also cultured with $1 \mu \mathrm{M}$ 5-bromo-2'-deoxyuridine (BrdU) (Sigma-Aldrich S.A., Madrid, Spain) for 48 hours.

This allowed for detection of BMSCs both in fresh tissue samples (fluorescent microscope) and immunohistochemical analysis (antibodies directed against BrdU and GFP). At the time of infection, the culture medium was replaced by $50 \mu \mathrm{L} / \mathrm{cm}^{2}$ of viral supernatant and $8 \mu \mathrm{g} / \mathrm{mL}$ of polybrene. Subsequently, the samples were incubated for 6 hours at $37^{\circ} \mathrm{C}$, and cells were allowed to grow in the standard medium for at least 48 hours before analysis of the expression of the transgenic marker.

\section{Animal Care and Anesthesia}

A total of 36 female Wistar Hannover rats (Harlan Interfauna Iberica SL, Barcelona, Spain), aged 3 months and weighing $200 \pm 20 \mathrm{~g}(180-220 \mathrm{~g}$ ), were used in these experiments. Rats were housed in groups of 7 in Plexiglas cages on wood chip bedding and maintained on a 12-hour light/12-hour dark cycle (light on at $7 \mathrm{AM}$ ). Animals had free access to commercial rodent food (CRM, Harlan Interfauna Iberica SL), and tap water was available ad libitum from polyethylene water bottles. The environmental conditions were constant: room temperature $20^{\circ} \mathrm{C}$ to $21^{\circ} \mathrm{C}$ and $50 \%$ to $60 \%$ relative humidity. All animals were handled according to the guidelines of the "Guide for the Care and Use of Laboratory Animals" issued by the American National Society for Medical Research. The study was approved by the institutional Animal Care and Use Committee of the Hospital Universitario Puerta de Hierro.

For induction of anesthesia, each rat was placed in an induction chamber, and a concentration of 5\% isoflurane (Forane, Abbott Laboratories Ltd, Kent, UK) vaporized in $100 \%$ oxygen at a flow rate of $8 \mathrm{~L} / \mathrm{min}$ was added. When animals had lost their palpebral reflex and jaw tone, tracheal intubation was performed using a 16-gauge polyethylene catheter (Abbott Ireland, Sligo, Ireland). Correct placement of the catheter was confirmed by $\mathrm{CO}_{2}$ infrared-absorption analysis, and the catheter was then taped in place and connected to a breathing machine (8050; Dräger Medizintechnik GMBH, Lubeck, Germany). We maintained an inspiratory time of 0.3 seconds, a respiratory rate of 60 cycles per minute, an inspiratory pressure of 14 mbar, and a fresh gas flow of $2 \mathrm{~L} / \mathrm{min}$ of oxygen. The inspired concentration of isoflurane was adjusted as necessary $(2.1 \%-2.3 \%)$ on the basis of assessment of the palpebral reflex and hemodynamic responses during instrumentation. Rectal temperature was maintained between $37^{\circ} \mathrm{C}$ and $38^{\circ} \mathrm{C}$ by means of a total temperature management system (Bair Huggers model 505; Augustine Medical Inc, Eden Prairie, Minn). A tail vein was catheterized with a 24-gauge polyethylene catheter (Abbott Ireland) for the infusion of morphine.

\section{Surgery}

Each animal underwent left pneumonectomy via a left posterolateral thoracotomy. Each structure of the hilum was individually ligated with a nonabsorbable 6-0 monofilament suture. Airway pressure was increased to the maximum (70 mbar) under water seal to check for air leaks from the bronchial stump.

In each case, $0.4 \mathrm{~mL}$ of Tissucol (Baxter S.L., Valencia, Spain) diluted to a thrombin concentration of $4 \mathrm{UI} / \mathrm{mL}$ was administered over the hilum. In the study group, 3 million labeled BMSCs diluted in $100 \mu \mathrm{L}$ of saline solution were injected under microscope visualization within the fibrin matrix in close vicinity to the bronchial stump. The chest was then closed by layers leaving a small bore drainage of $16 \mathrm{~F}$ until the animal breathed by itself. All procedures were performed by the same surgeon (D.G.A.).

\section{Tissue Sampling}

Seven animals in each group were euthanized after 7 days, and 11 animals per group were euthanized on day 21. All animals were anesthetized and intubated again in the same manner. A re-thoracotomy was performed, and the macroscopic appearance of the pleural space was recorded. The patency of the bronchial stump was tested by increasing airway pressure to a maximum of $70 \mathrm{mbar}$, and animals were euthanized with an intracardiac $50 \mathrm{meq} / \mathrm{kg}$ potassium chloride injection (UCB Pharma, SA, Barcelona, Spain). The 3 distal rings of the bronchial stump were resected en bloc. Samples were fixed for histologic study for 12 hours in $4 \%$ paraformaldehyde in $0.1 \mathrm{~mol} / \mathrm{L}$ PBS, pH 7.4. After bronchial stump specimens were rinsed with ice-cold $20 \%$ sucrose in PBS for 1 hour, they were incubated in 30\% sucrose and PBS overnight at $4{ }^{\circ} \mathrm{C}$. The tissue was washed in PBS and embedded in optimum cutting temperature medium (TAAB Lab, Aldermaston Berks, UK) and cut in a cryostat at $5 \mu \mathrm{m}$. They were mounted on glass slides for histologic study after hematoxylin-eosin staining.

For immunohistochemical studies, adjacent slides were placed in a boiled citrate buffer $(\mathrm{pH} 6)$ in a microwave oven $(650-720 \mathrm{~W})$. After rinsing in PBS, the sections were exposed to $3 \% \mathrm{H}_{2} \mathrm{O}_{2}$ for 30 minutes to quench endogenous peroxidase activity. Before incubation of primary antibodies, nonspecific binding was blocked for 1 hour with $3 \%$ normal serum from the species in which the secondary antibody was raised, with $0.25 \%$ Triton X-100 in PBS. The primary antibodies used were directed against antiBrdU monoclonal antibody (1:100; Chemicon International, Temecula, Calif), anti-GFP (1:100; Serotec, Kidlington, UK), or anti Ki-67 (1:100; Lab Vision Westinghouse Dr, Fremont, Calif). The sections were incubated with secondary antibodies conjugated to biotin, 1:200 (Vector Inc, Burlingame, Calif). Subsequently, the sections incubated with secondary antibodies conjugated to biotin were washed in PBS and incubated with avidin-biotin-horseradish peroxidase complex (ABC reagent; Vector Inc). $3^{\prime}, 3^{\prime}$-diaminobenzidine was used as a chromogen. Control slides lacking primary or secondary antibodies were used. The sections were studied using light and fluorescent microscopy.

\section{Variables}

All variables were measured on both days 7 and 21. We checked for the presence of a bronchial fistula, and the rupture pressure of the stump was tested at increasing airway pressures applied with the ventilator. Both macroscopic and microscopic variables were reported, and marked stem cells were sought in the histologic study.

The degree of adhesions was defined macroscopically as mild if they could be dissected bluntly, moderate if they were located around the hilum and some sharp dissection was needed, intense if they were extended to the upper mediastinum, and very intense if the whole pleural space was obliterated. In the microscopic stage, restitutio ad integrum was 
defined as a completely normal epithelium, submucosa, and cartilage with neovascularization.

\section{Statistical Design}

This was an experimental, prospective, and randomized study. During tissue harvest, the surgeon and pathologist were blinded to animal groups.

The Statistical Package for the Social Sciences 14.0 (SPSS Inc, Chicago, Ill) was used for statistical analysis. We used a chi-square test for qualitative variables, corrected chi-square for estimated frequencies less than 5 , and the Fisher exact test when required.

\section{RESULTS}

There were no signs of dehiscence at the time of rethoracotomy in any animal, not even when airway pressure was increased to 70 mbar. Pleural secretions, when present, were always serous.

\section{Day 7}

The macroscopic appearance at day 7 was similar in both groups, except regarding the presence of adhesions, which was less in the BMSC group $(P=.042)$ (Table 1). Histologic analysis did not show any difference on the seventh day. There were no cases of restitutio ad integrum.

At this stage of the cicatrization process, light microscopy study showed intense inflammation with diffuse ulceration of the mucosa, intense neovascularization, and signs of infection with foreign body granulomas in the peribronchial pleura (Table 1).

We identified stem cells in the samples obtained, with a mean of 5 cells per field (range, 1-6) showing the morphologic features of fibroblasts, chondrocytes, and adipocytes. Among them, 2.5\% showed cell proliferation markers (Ki 67) (Figure 1).

\section{Day 21}

On day 21, macroscopic appearance was also similar between both groups, again with the exception of the presence of adhesions, which was significantly less in the BMSC group $(P=.031)$ (Table 2). The histologic examination at this time showed a significant number of stumps in the BMSC group with complete restoration of the normal architecture and morphology of the mucosa and bronchial wall (Figure 2), as well as less inflammation in every layer compared with the control group (Table 2). We observed the same proportion of stem cells with mesenchymal morphologic features as in the BMSC group on day 7 (Figure 3), but with less expression of Ki 67 (1\%).

\section{DISCUSSION}

The critical factor that led to these results is the lower level of inflammation in the BMSC group. Inflammatory cells play a pivotal role in wound healing. They assist in microbial decontamination, produce multiple growth factors that promote the healing process, and help in the clearance of cellular death and tissue remodeling. Nevertheless, recent skin
TABLE 1. Day 7

\begin{tabular}{|c|c|c|c|}
\hline Macroscopic & Control $(n=7)$ & $\operatorname{BMSC}(n=7)$ & $\boldsymbol{P}$ \\
\hline \multicolumn{4}{|l|}{ Adhesions } \\
\hline No & $1(14.3 \%)$ & $5(71.4 \%)$ & .042 \\
\hline Mild-moderate & $4(57.1 \%)$ & 0 & \\
\hline Intense-very intense & $2(28.6 \%)$ & $2(28.6 \%)$ & \\
\hline \multicolumn{4}{|l|}{ Bronchial stump } \\
\hline Normal & $3(42.9 \%)$ & $6(85.7 \%)$ & NS \\
\hline Capillaries & $1(14.3 \%)$ & $1(14.3 \%)$ & \\
\hline Abscesses & $2(28.6 \%)$ & 0 & \\
\hline Necrotic & $1(14.3 \%)$ & 0 & \\
\hline \multicolumn{4}{|l|}{ Microscopic } \\
\hline Restitutio ad integrum & 0 & 0 & NS \\
\hline \multicolumn{4}{|l|}{ Mucosa } \\
\hline Severe inflammation & $5(71.4 \%)$ & $5(71.4 \%)$ & NS \\
\hline Diffuse fibrosis & 0 & 0 & NS \\
\hline Diffuse ulceration & $5(71.4 \%)$ & $6(85.7 \%)$ & NS \\
\hline Infection & $6(85.7 \%)$ & $5(71.4 \%)$ & NS \\
\hline Neovascularization & $6(85.7 \%)$ & $7(100 \%)$ & NS \\
\hline \multicolumn{4}{|l|}{ Cartilage } \\
\hline Severe inflammation & $4(57.1 \%)$ & $4(57.1 \%)$ & NS \\
\hline Infection & $6(85.7 \%)$ & $5(71.4 \%)$ & NS \\
\hline \multicolumn{4}{|l|}{ Perihilar pleura } \\
\hline $\begin{array}{c}\text { Moderate-severe } \\
\text { inflammation }\end{array}$ & $7(100 \%)$ & $7(100 \%)$ & NS \\
\hline Diffuse fibrosis & 0 & $1(14.3 \%)$ & NS \\
\hline Foreign body granuloma & $7(100 \%)$ & $7(100 \%)$ & NS \\
\hline Infection & $6(85.7 \%)$ & $6(85.7 \%)$ & NS \\
\hline Neovascularization & $6(85.7 \%)$ & $6(85.7 \%)$ & NS \\
\hline
\end{tabular}

$B M S C$, Bone marrow-derived stem cell; $N S$, not significant.

studies have shown that inflammatory cells may not be that effective in wound healing in a clean and aseptic scenario, such as a surgical wound. ${ }^{11}$ In this environment, inflammation may act as a negative factor, as several experimental studies have shown. Martin and colleagues ${ }^{12}$

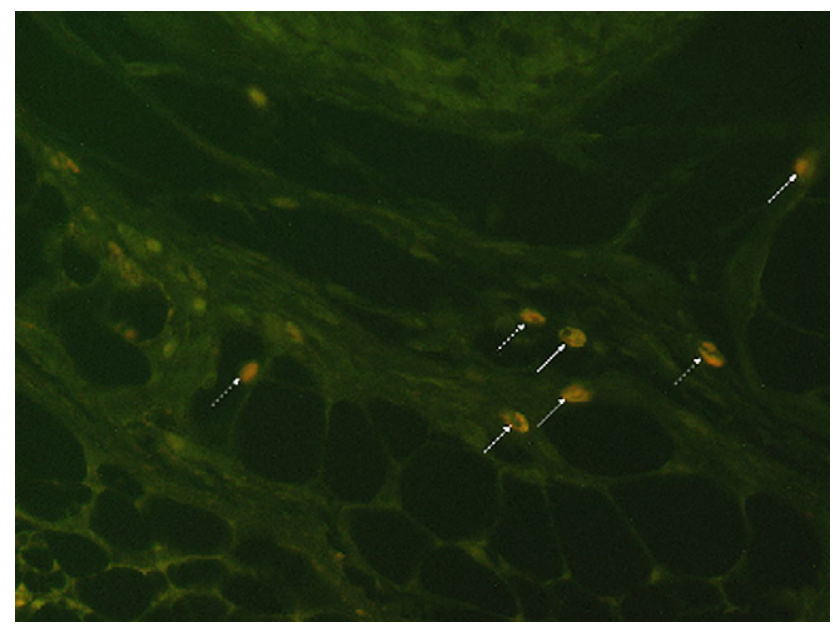

FIGURE 1. BMSCs expressing GFP, some of them also co-expressing proliferation marker Ki67 (white arrows) at day 7 (fluorescence and immunohistochemical study with anti-Ki67 antibodies, $40 \times$ ). 
TABLE 2. Day 21

\begin{tabular}{|c|c|c|c|}
\hline Macroscopic & Control $(n=11)$ & $\operatorname{BMSC}(\mathbf{n}=11)$ & $P$ \\
\hline \multicolumn{4}{|l|}{ Adhesions } \\
\hline No & 0 & $6(54.5 \%)$ & .031 \\
\hline Mild-moderate & $6(54.5 \%)$ & $5(45.5 \%)$ & \\
\hline Intense-very intense & $5(45.5 \%)$ & 0 & \\
\hline \multicolumn{4}{|l|}{ Bronchial stump } \\
\hline Normal & $5(45.5 \%)$ & $5(45.5 \%)$ & .226 \\
\hline Capillaries & $2(18.2 \%)$ & $3(27.3 \%)$ & \\
\hline Abscesses & $4(37.3 \%)$ & $3(27.2 \%)$ & \\
\hline \multicolumn{4}{|l|}{ Microscopic } \\
\hline Restitutio ad integrum & $1(9.09 \%)$ & $7(63.6 \%)$ & .012 \\
\hline \multicolumn{4}{|l|}{ Mucosa } \\
\hline Severe inflammation & $6(54.5 \%)$ & $1(9.1 \%)$ & .014 \\
\hline Diffuse fibrosis & 0 & $2(18.2 \%)$ & NS \\
\hline Diffuse ulceration & $4(36.4 \%)$ & $2(18.2 \%)$ & NS \\
\hline Infection & $5(45.5 \%)$ & $3(27.3 \%)$ & NS \\
\hline Neovascularization & $8(72.7 \%)$ & $10(90.9 \%)$ & NS \\
\hline \multicolumn{4}{|l|}{ Cartilage } \\
\hline Severe inflammation & $5(45.5 \%)$ & $1(9.1 \%)$ & .020 \\
\hline Infection & $5(45.5 \%)$ & $2(18.2 \%)$ & NS \\
\hline \multicolumn{4}{|l|}{ Perihilar pleura } \\
\hline $\begin{array}{c}\text { Moderate-severe } \\
\text { inflammation }\end{array}$ & $6(54.5 \%)$ & $2(18.2 \%)$ & .020 \\
\hline Diffuse fibrosis & $1(9.1 \%)$ & 0 & NS \\
\hline Foreign body granuloma & $2(18.2 \%)$ & $1(9.1 \%)$ & NS \\
\hline Infection & $6(54.5 \%)$ & $6(54.5 \%)$ & NS \\
\hline Neovascularization & $9(81.8 \%)$ & $6(54.5 \%)$ & NS \\
\hline
\end{tabular}

$B M S C$, Bone marrow-derived stem cells; $N S$, not significant.

recently showed how PU.1 null rats (without macrophages or neutrophils) healed without any inflammation or scar at the wound site, whereas rats lacking the inhibitor of neutrophil protease secretion (an anti-inflammatory factor) had an impaired wound healing process. ${ }^{13}$

Our results confirm this hypothesis. We observed significantly less inflammation in every layer of the bronchial

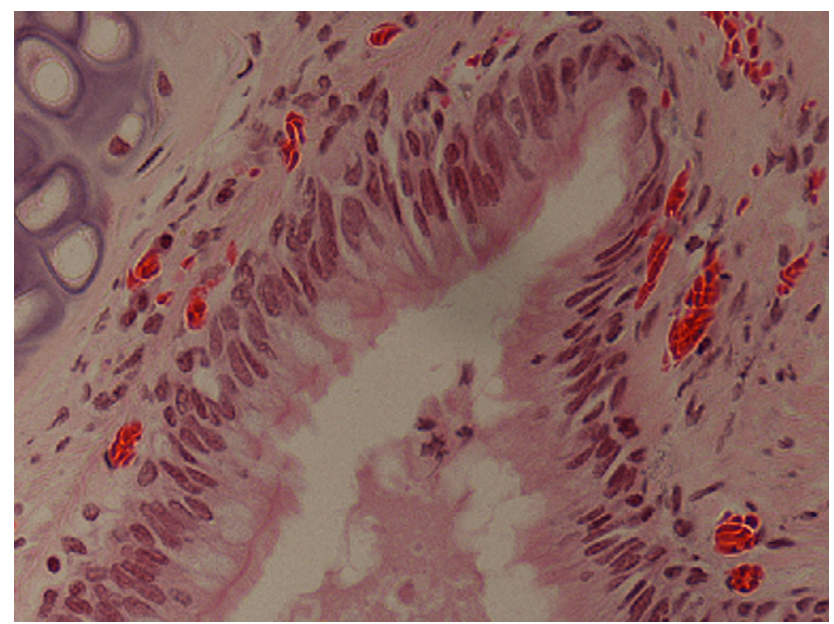

FIGURE 2. Bronchial stump at 21 days. Perfect restoration of the mucosa and bronchial wall (hematoxylin-eosin $20 \times$ ).

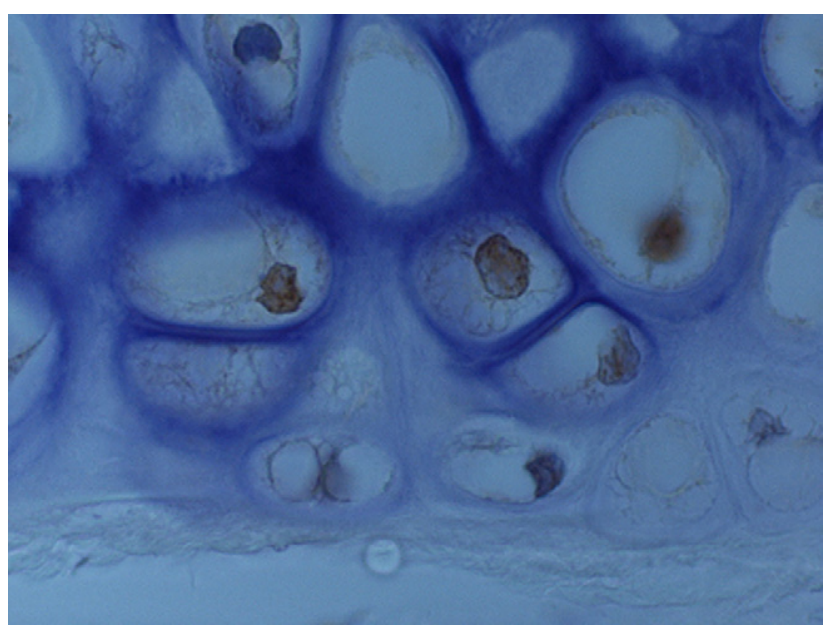

FIGURE 3. BMSCs with morphologic features of chondrocytes at day 21 (immunohistochemical study with anti-BrdU antibodies, 40×).

stump in the BMSC group. Moreover, in this group the stump was completely restored, showing no signs of scar formation, with the histologic features of an intact bronchial epithelium and cartilage.

There is also experimental evidence that these cells reduce collagen fiber accumulation in a model with bleomycininduced pulmonary fibrosis, ${ }^{14}$ reinforcing the idea that stem cells may influence the healing process in terms of tissue restitution without scar formation.

Notably, we also observed a significantly lower level of adhesions in the BMSC group compared with the control group. In a similar experimental study in colon anastomosis using sutures with adult stem cells, Pascual and coworkers ${ }^{15}$ observed fewer adhesions during the first postoperative week. This finding is the macroscopic correlation of the limited inflammatory activity shown under the light microscope.

Little is known about the pathophysiologic pathways underlying these effects. Researchers postulate that BMSCs have a low inherent immunogenicity and may play a role in the mechanisms that control the immunologic response to an injury, because in vivo they show the ability to inhibit both the proliferation of $\mathrm{T}$ cells and secretion of proinflammatory cytokines. ${ }^{16}$

Another important issue that arises in the use of stem cells is the method of administration and its vehicle. Shigemura and colleagues ${ }^{17}$ showed that topical administration of autologous adult stem cells in a polyglycolic acid matrix after lung volume reduction surgery in rats resulted in better alveolar and vascular regeneration, as well as improved respiratory function, with an increase in oxygenation and exercise capacity in those animals receiving stem cells. In another experimental model, Wong and colleagues ${ }^{18}$ showed that after naphthalene-induced lung injury, endotracheal administration of bone marrow-derived stem cells allowed for regeneration of the respiratory epithelium, remaining with proliferation capacity for at least 120 days. 
We isolated viable stem cells during the first week after topical administration using a fibrin-modified matrix (Tissu$\mathrm{col})$. It is remarkable that the same proportion of viable stem cells was seen at week 3 . This can be explained because the matrix may act as a reservoir for viable stem cells that can migrate to the bronchial stump later in the healing process.

\section{Study Limitations}

One of the major limitations of this study is that although the matrix has been shown to be an acceptable biomaterial (it is adherent for cells, allows for migration, and finally degrades), it contains human and bovine proteins, which surely enhanced the inflammatory activity in the recipient rat. The reason for using this solution was that its clinical use in thoracic surgery is common. We do believe, however, that a better ratio of viable cells with less of an inflammatory response can be obtained using different matrices. We are currently using autologous platelet-enriched plasma with encouraging results.

Another limitation is that the minimum amount of cells needed to achieve clinical results is unknown. We have used 3 million BMSCs in $100 \mu \mathrm{L}$ of saline because that is the maximum concentration of cells that can be efficiently injected through a needle $0.4 \mathrm{~mm}$ in diameter. The mediastinal pleura after a pneumonectomy is a hostile environment for cells to graft because it is not completely sterile and is in constant movement, so we wanted to have the highest concentration of stem cells around the bronchial stump. It would be interesting to design a dose-response study to determine the adequate concentration of BMSCs needed to obtain good results.

One important recent controversy is the ability of BMSCs to give rise to cells of a different lineage, known as cellular transdifferentiation. There have been in vivo and in vitro reports supporting this capability, ${ }^{3,4,19-21}$ whereas others suggest that those findings may represent cellular fusions with resident cells or even genetic changes that adult stem cells acquire during in vitro processing. ${ }^{22-25}$ We have not observed any BMSCs with the morphologic features of epithelial cells in the samples analyzed, and we believe this is a crucial point in determining whether BMSCs can be used to obtain functional lung tissue. We hope that further studies will help shed light on this issue.

\section{CONCLUSIONS}

Topical administration of rat bone marrow-derived stem cells in the conditions of our experiment improves the healing process of the bronchial stump, leading to fewer adhesions, less inflammation, and complete histologic restoration.

The authors thank Dr I. Millan for advice and support with the statistical design and processing of the data.

\section{References}

1. Weissman IL, Anderson DJ, Gage F. Stem and progenitor cells: origins, phenotypes, lineage commitments, and transdifferentiations. Annu Rev Cell Dev Biol. 2001; 17:387-403.

2. Donovan PJ, Gearhart J. The end of the beginning for pluripotent stem cells. $\mathrm{Na}$ ture. 2001;414:129-31.

3. Herzog EL, Chai L, Krause DS. Plasticity of marrow-derived stem cells. Blood. 2003;102:3483-93.

4. Korbling M, Ratz RL, Khanna A, Ruifrok AC, Rondon G, Albitar M, et al. Hepatocytes and epithelial cells of donor origin in recipients of peripheral-blood stem cells. N Engl J Med. 2002;346:738-46.

5. Le Blanc K, Ringdén O. Immunobiology of human mesenchymal stem cells and future use in hematopoietic stem cell transplantation. Biol Blood Marrow Transplant. 2005;11:321-34

6. Al-Kattan K, Cattelani L, Goldstraw P. Bronchopleural fistula after pneumonectomy for lung cancer. Eur J Cardiothorac Surg. 1995;9:479-82.

7. Wright CD, Wain JC, Mathisen DJ, Grillo HC. Postpneumonectomy bronchopleural fístula alter sutured bronchial closure: incidence, risk factors and management. J Thorac Cardiovasc Surg. 1996;112:1367-71.

8. Sirbu H, Busch T, Aleksic I, Schreiner W, Oster O, Dalichau H. Bronchopleural fistula in the surgery of non-small cell lung cancer: incidence, risk factors and management. Ann Thorac Cardiovasc Surg. 2001;7:330-6.

9. Asamura H, Naruke T, Tshuchiya R, Goya T, Kondo H, Suemasu K. Bronchopleural fistulas associated with lung cancer operations: univariate and multivariate analysis of risk factors, management and outcome. J Thorac Cardiovasc Surg. 1992; 104:1456-64

10. Vaquero J, Zurita M, Oya S, Santos M. Cell therapy using bone marrow stromal cells in chronic paraplegic rats: systemic or local administration? Neurosci Lett. 2006;398:129-34.

11. Szpaderszka A, DiPietro LA. Inflammation in surgical wound healing: friend or foe? Surgery. 2005; 137:571-3.

12. Martin P, D'Souza D, Martin J, Grose R, Cooper L, Maki R, et al. Wound healing in the PU.1 null mouse-tissue repair is not dependent on inflammatory cells. Curr Biol. 2003; 13:1122-8.

13. Aschroft GS, Lei K, Jin W, Longenecker G, Kulkarni AB, Greenwell-Wild T, et al. Secretory leukocyte protease inhibitor mediates non-redundant functions necessary for normal wound healing. Nat Med. 2000;6:1147-53.

14. Ortiz LA, Dutreil M, Fattman C, Pandey AC, Torres G, Go K, et al. Interleukin 1 receptor antagonist mediates the antiinflammatory and antifibrotic effect of mesenchymal stem cells during lung injury. Proc Natl Acad Sci U S A. 2007;104: 11002-7.

15. Pascual I, Fernández de Miguel G, Gómez Pinedo UA, de Miguel F, Arranz MG, García-Olmo D. Adipose-derived mesenchymal stem cells in biosutures do not improve healing of rat colonic anastomoses. Br J Surg. 2008;95:1180-4.

16. Phinney DG. Biochemical heterogeneity of mesenchymal stem cell populations: clues to their therapeutic efficacy. Cell Cycle. 2007;6:2884-9.

17. Shigemura N, Okumura N, Mizuno S, Imanisi Y, Matsuyama A, Shiono H, et al Lung tissue engineering technique with adipose stromal cells improves surgical outcome for pulmonary emphysema. Am J Respir Crit Care Med. 2006;174: 1199-205.

18. Wong AP, Keating A, Lu WY, Duchesneau P, Wang X, Sacher A, et al. Identification of a bone marrow-derived epithelial-like population capable of repopulating injured mouse airway epithelium. J Clin Invest. 2009;119:336-48.

19. Horwitz EM. Stem cell plasticity: a new image of the bone marrow stem cell. Curr Opin Pediatr. 2003;15:32-7.

20. Petersen BE, Terada N. Stem cells: a journey into a new frontier. J Am Soc Nephrol. 2001;12:1773-80.

21. Clarke DL, Johansson CB, Wilbertz J, Veress B, Nilson E, Karlstrom H, et al. Generalized potential of adult neural stem cells. Science. 2000;288:1660-3.

22. Morshead CM, Benveniste P, Iscove NN, van der Kooy D. Hematopoietic competence is a rare property of neural stem cells that may depend on genetic and epigenetic alterations. Nat Med. 2002;8:268-73.

23. Wagers AJ, Sherwood RI, Christensen JL, Weissman IL. Little evidence of developmental plasticity of adult stem hematopoietic cells. Science. 2002;297:2256-9.

24. Wagers AJ, Weissman IL. Plasticity of adults stem cells. Cell. 2004;116:639-48

25. Álvarez-Dolado M, Pardal R, García-Verdugo JM, Fike JR, Lee HO, Pfeffer K, et al. Fusion on bone-marrow-derived cells with Purkinje neurons, cardiomyocytes and hepatocytes. Nature. 2003;425:968-73. 